\title{
Treatment of ureterolithiasis with the use of percutaneous antegrade ureterolithotripsy
}

\author{
A. I. Sagalevich, O. S. Vozianov, V. V. Ozhohin, B. V. Dzhuran, V. V. Kogut, \\ F. Z. Gaysenyuk, R. V. Sergiychuk
}

National Medical Academy of Postgraduate Education named after P. L. Shupyk, Kyiv, Ukraine

Key words: ureterolithiasis, percutaneous lithotripsy, mini percutaneous nephrolithotripsy.

\section{Zaporozhye} medical journal 2018; 20 (2), 162-166 Dol:

$10.14739 / 2310-1210$ 2018.2.124838

\section{E-mail:}

b.dzhuran@yahoo.com

Study purpose - to assess the possibility of percutaneous antegrade ureterolithotripsy as an alternative treatment for patients with large calculi of the proximal part of ureter.

Patients and methods. Results of 75 mini percutaneous antegrade ureterolithotripsy with contact lithotripsy were studied. The mean size of the ureteral calculi was $1.8 \pm 0.7 \mathrm{~cm}$. The operations were performed with epidural anesthesia with intravenous sedation, in the patient's position "on the abdomen" in $62(82.7 \%)$ cases and in the patient's position "on the back" in $13(17.3 \%)$ cases. Puncture of the renal cavity system was performed with combined ultrasound and fluoroscopic guidance. Accesses were performed through the lower calices group in $14(18.7 \%)$ cases, through the middle calices group in $39(52.0 \%)$, and through the upper calices group in $22(29.3 \%)$ cases.

Results. The mean time of mini percutaneous antegrade ureterolithotripsy was $58.5 \pm 15.4 \mathrm{~min}$, while the stone free rate was achieved in all $100 \%$ of patients. The mean level of hemoglobin drop was not more than $15.5 \pm 5.4 \mathrm{GM} / \mathrm{DL}$ In the postoperative period, aggravation of pyelonephritis was noted in $8(10.6 \%)$ patients. Nephrostomy drainage followed percutaneous antegrade ureterolithotripsy in $24(32.0 \%)$ cases, nephrostomy drainage and internal ureteral $\mathrm{JJ}$ stent in $33(44.0 \%)$, and the operation was ended with a tubeless method with only ureteral $\mathrm{JJ}$ stent placement in $14(18.7 \%)$ cases. Nephrostomy drainage, as well as ureteral stants (with tubeless method), were removed in 1-2 days. The mean period of postoperative stay of patients in the hospital was $2.3 \pm 0.8$ days. It was noted that antegrade fiberureteropyeloscopy is an extremely time-consuming and cost-demanding method, as an alternative to which may be percutaneous antegrade ureterolithotripsy with use of mini-nephroscope tubes.

Conclusions. Analysis of urolithiasis treatment with the method of mini percutaneous antegrade ureterolithotripsy indicates that this method is an attractive direction in the treatment of patients with large calculi of the proximal parts of ureter that allows achievement of the full stone free rate state, time of surgical treatment and hospital stay for patients with this pathology reduction.

Киючові слова: уретеролітіаз, перкутанна мітотрипсія, мініперкутанна нефролітотрипсія.

Запорізький медичний журнал. - 2018. T. 20, № 2(107). C. $162-166$

Киючевые слова: уретеролитиаз, перкутанная митотрипсия, миниперкутанная нефролитотрипсия.

\section{Перкутанна антеградна уретеролітотрипсія в мікуванні уретеролітіазу}

\section{А. І. Сагалевич, О. С. Возіанов, В. В. Ожогін, Б. В., Ажуран, В. В. Когут, Ф. 3. Гайсенюк, Р. В. Сергійчук}

Мета роботи - оцінити можливість антеградної перкутанної уретеролітотрипсії як альтернативного варіанта лікування пацієнтів із великими конкрементами проксимального відділу сечоводу.

Матеріали та методи. Вивчили результати 75 мініперкутанних антеградних уретеролітотрипсій із контактною літотрипсією. Середній розмір каменю сечоводу становив $1,8 \pm 0,7$ см. Операції виконали під епідуральною анестезією з внутрішньовенною седацією в положенні хворого на животі в 62 (82,7 \%) випадках, в 13 (17,3\%) випадках -у положенні хворого на спині. Пункцію порожнинної системи нирки виконали під комбінованим ультразвуковим і флюороскопічним наведенням. Через нижнюгрупу чашечок доступи виконали в 14 (18,7 \%) випадках, через середню - в 39 (52,0 \%), через верхню - у 22 (29,3 \%) випадках.

Результати. Середній час антеградної мініперкутанної уретеролітотрипсії становив 58,5 \pm 15,4 хв, стан «stone free rate» досягнуто у 100 \% хворих. Середній рівень падіння гемоглобіну становив не більше ніж 15,5 \pm 5,4 г/л. У післяопераційному періоді загострення пієлонефриту визначили у 8 (10,6 \%) хворих. Операції завершувалися встановленням нефрростомічного дренажу у 24 (32,0 \%) випадках, нефростомічного дренажу та внутрішнього сечовідного JJ стенту у 33 (44,0 \%), в 14 (18,7 \%) випадках операція закінчувалася бездренажним методом (tubeless) із встановленням тільки сечовідного JJ стенту. Нефростомічний дренаж, як і сечоводні стенти (при tubeless), видаляли на 1-2 добу. Середній термін післяопераційного перебування хворих у стаціонарі становив 2,3 \pm 0,8 доби. Антеградна фіброуретеропієлоскопія - вкрай трудомісткий та економічно затратний метод, альтернативою якому може бути перкутанна антеградна уретеролітотрипсія з використанням тубусів мінінефроскопа.

Висновки. Аналіз лікування уролітіазу методом антеградної мініперкутанної уретеролітотрипсії свідчить, що ця методика є перспективним напрямом у лікуванні хворих із великими конкрементами проксимальних відділів сечоводів, що дає можливість досягти повного стану «stone free rate», скоротити час операції та терміни перебування у стаціонарі хворих із цією патологією.

\section{Перкутанная антеградная уретеролитотрипсия в лечении уретеролитиаза}

\section{А. И. Сагалевич, А. С. Возианов, В. В. Ожогин, Б. В. Ажуран, В. В. Когут, Ф. З. Гайсенюк, Р. В. Сергийчук}

Цель работы - оценить возможность антеградной перкутанной уретеролитотрипсии как альтернативного варианта лечения пациентов с крупными конкрементами проксимального отдела мочеточника.

Материалы и методы. Изучены результаты 75 миниперкутанных антеградных уретеролитотрипсий с контактной литотрипсией. Средний размер камня мочеточника составил 1,8 \pm 0,7 см. Операции проводили под эпидуральной 
анестезией с внутривенной седацией в положении больного на животе в 62 (82,7 \%) случаях, в 13 (17,3 \%) случаях в положении больного на спине. Пункцию полостной системы почки проводили под комбинированным ультразвуковым и флюороскопическим наведением. Через нижнюю группу чашечек доступы выполнены в 14 (18,7 \%) случаях, через среднюю - в 39 (52,0 \%), через верхнюю - в 22 (29,3 \%) случаях.

Результаты. Среднее время проведения антеградной миниперкутанной уретеролитотрипсии составило $58,5 \pm$ 15,4 мин, состояние «stone free rate» достигнуто у 100 \% больных. Средний уровень падения гемоглобина составил не более 15,5 $\pm 5,4$ г/л. В послеоперационном периоде обострение пиелонефрита отмечено у 8 (10,6 \%) больных. Операции завершались установкой нефростомического дренажа в 24 (32,0 \%) случаях, нефростомического дренажа и внутреннего мочеточникового JJ стента в 33 (44,0 \%), в 14 (18,7 \%) случаях операция заканчивалась бездренажным методом (tubeless) с установкой только мочеточникового JJ стента. Нефростомический дренаж, как и мочеточниковые стенды (при tubeless), удаляли на 1-2 сутки. Средние сроки послеоперационного пребывания больных в стационаре составили 2,3 \pm 0,8 суток. Отмечено, что антеградная фиброуретеропиелоскопия является крайне трудоемким и экономически затратным методом, альтернативой которого может являться перкутанная антеградная уретеролитотрипсия с использованием тубусов мининефроскопа.

Выводы. Анализ лечения уролитиаза методом антеградной миниперкутанной уретеролитотрипсии свидетельствует, что данная методика является перспективным направлением в лечении больных с крупными конкрементами проксимальных отделов мочеточников, позволяет достичь полного состояния «stone free rate», сократить время оперативного лечения и сроки нахождения в стационаре у больных с данной патологией.

\section{Introduction}

Today, the tactics of patients with ureteral calculi treatment is highlighted in up-to-date urological guidelines and recommendations, where a large arsenal of methods exists for this pathology treatment. Extracorporeal shock wave lithotripsy (ESWL), laparoscopic and retro-peritoneoscopic ureterolithotripsy, transurethral retrograde contact ureterolithotripsy and percutaneous nephrolithotripsy (PNL) are widely applied [1].

Over the past 15 years, retrograde ureteroscopy has been specified as a minimally invasive method for the ureteral calculi superior treatment in efficiency of ESWL $[1,2]$. Recently, advances in endoscopic instruments, especially the new-generation flexible ureteroscopes and the holmium laser contact lithitriptors, have made it possible for the retrograde ureteroscopy to become the first line option for most ureteral calculi and even small intrarenal calculi. The combination of these tools allows the treatment of ureterolithiasis against a background of short-term treatment with high postoperative efficacy and low complication rates $[4,5]$. However, in certain circumstances the retrograde ureteroscopy (RURS) is not successful due to anatomical and functional individual characteristics of the upper urinary tract (anatomical narrowness and pathological tortuosity of the ureter) that makes it difficult to access to the middle and upper parts of the ureter. Large (more than $1.0 \mathrm{~cm}$ ) or impacted calculi of the proximal ureteral parts result in decrease of the method effectiveness and increase the percentage of intraoperative complications, including proximal migration of both the calculus and its fragments into the renal cavity system [10].

In such circumstances, percutaneous antegrade ureteroscopy (PAURS) performed through percutaneous transparenchymal access to the upper urinary tract is often the only endoscopic alternative to the proximal and middle part of ureter calculi treatment, when RURS cannot be performed or can cause various complications [6-9]. Percutaneous antegrade stones removal from the proximal ureteral parts is also used when ESWL is prognostically impossible (high density of the calculus, stricture of the renal duct, etc.) or has failed, and retrograde access is difficult, as well as with ureterolithiasis of the transplanted kidney $[3,7]$.
Thus, despite the availability of various methods of ureterolithiasis treatment, there is still no ideal, effective and absolutely safe method of calculi removal from the middle and upper third of the ureter. A number of other factors influencing the choice of methodologies should be noted, in particular, the method available in the clinic with its pros and cons is often offered to a patient. At the same time, priority is given to the method that is better mastered and for which technical support is provided. In turn, the technical level of hospital provision, availability of various endoscopes, fiberscopes, laser lithotriptors, X-ray and ultrasound devices, and most importantly - qualified and sufficiently experienced in the above method personnel, are crucial when applying a method or their combination in the treatment of proximal ureterolithiasis.

\section{Study purpose}

To assess the possibility of percutaneous antegrade ureterolithotripsy as an alternative treatment for patients with large calculi of the proximal part of ureter.

\section{Patients and methods}

During the period from 2014 to 2017,75 mini percutaneous antegrade ureterolithotripsy (PAULT) with contact lithotripsy were performed in P. L. Shupyk National Medical Academy of Postgraduate Education, on the basis of the Kyiv Regional Hospital and Kyiv City Hospital No 6. Among them $54(72.0 \%)$ operations were performed as monotherapy and in $21(28.0 \%)$ cases - as a stage of surgical treatment (during percutaneous nephrolithotripsy surgery). Among the patients, there were 34 (45.3\%) women and 41 (54.7\%) men aged from 23 to 69 years. The mean size of the ureteral calculi was $1.8 \pm 0.7 \mathrm{~cm}$. There was bilateral ureterolithiasis in $8(10.1 \%)$ patients.

Preoperatively, patients were examined according to generally accepted criteria: clinical blood and urine analysis; biochemical blood parameters; bacterial urine culture with antibiotics sensitivity test (if the clinical situation allowed); ultrasound examination of the urinary tract; KUB and excretory urography; SCT and dynamic scintigraphy (if the methods were required).
Запорожский медицинский журнал. - 2018. T. 20, № 2(107). C. $162-166$ 
When performing endourological operations, the following endoscopic equipment, manufactured by Karl Storz (Germany), was used: a rigid ureteroscope 6.8-8.0 Ch, a FLEX $X^{2}$ fiberureteropyeloscope $(7.5 \mathrm{Ch})$ and a rigid mini-nephroscope with a set of tubes $(14,16,21 \mathrm{Ch})$ for mini-percutaneous nephrolithotripsy performing (m-PNL). All operations were performed with epidural anesthesia with intravenous sedation, in the patient's position "on the abdomen" (prone position) in $62(82.7 \%)$ cases and in the patient's position "on the back" (supine position Valdivia position) in $13(17.3 \%)$ cases. Puncture of the renal cavity system was performed with combined ultrasound and fluoroscopic guidance. Access to the kidney was performed through the lower, middle and upper calices groups. The choice of an access point was based on geometric anatomy between the caliceal neck and the proximal ureter part. We tried to access to pyelocaliceal system through that calix, which axis of the neck had an obtuse angle with the axis of the upper third ureter. Thus, accesses were performed through the lower calices group in $14(18.7 \%)$ cases, through the middle calices group in 39 (52.0\%), and through the upper calices group in $22(29.3 \%)$ cases.

In a number of cases with multiple kidney calculi additional access to the kidney cavity system was used that occurred in $11(14.7 \%)$ patients.

Direct contact lithotripsy was performed using a holmium laser of the Dornier $\mathrm{H}-20$ and a pneumatic lithotriptor of Karl Storz.

It should be noted that all endoscopic interventions were performed only in the absence of an acute phase of inflammatory process in the upper urinary tract (UUT). One of the predisposing factors contributing to the percutaneous antegrade ureterolithotripsy performance was the presence of detected earlier functioning percutaneous nephrostomy for obstructive calculi of the proximal parts of ureter in 23 (30.7\%) cases.

The statistical processing of the data was carried out using the Statistica software package (version 6.0, StatSoft Inc., USA). Reliability of the difference in a number of parameters between groups of patients was determined on the basis of Student's t-test. The results of the analysis were considered statistically significant at the level of $P<0.05$.

\section{Results and discussion}

When choosing the tactics for calculi of the proximal part of ureter treatment, we took into account the following criteria: the size of the calculus and the duration of its "standing" in the ureter, state of urodynamics (degree of pyelocaliceal system dilatation), functional state of the kidney and anatomical state of the ureter below calculus standing (its luminal diameter, tortuosity, presence of strictures below the calculus standing).

We determined the following indications for percutaneous nephrolithotripsy (or m-PNL) with calculi of the proximal part of ureter: calculi with a total mass of more than 1.0-1.5 $\mathrm{cm}$; technical difficulties in performing the retrograde ureteroscopy; technical contraindications to remote lithotripsy or lack of remote crushing efficacy.

Acute purulent obstructive pyelonephritis (or pionephrosis) against the background of upper or middle third of the ureter calculus; the presence of extensive ureter stricture, its high shift, an additional vessel of the kidney should be considered as contraindications to the PAULT application. In such cases surgical correction of these states is indicated above all.

The percutaneous antegrade ureteroscopy was performed directly after the percutaneous access to the kidney using mini-nephroscope tubes and doing the nephroscopy, followed by entering the nephroscope optics in the proximal part of ureter and performing the ureteroscopy.

It was noted that the performance of both $\mathrm{m}-\mathrm{PNL}$ and percutaneous antegrade ureterolithotripsy allowed only lithoextraction of whole calculi $0.5-0.7 \mathrm{~cm}$ from the proximal parts of ureter or from the kidney cavity moved to the pelvis during ureter catheterization before the main stage of $\mathrm{m}-\mathrm{PNL}$ performance. In particular, this variant of litholapaxy was successfully performed in 21 (28.0\%) cases, while the time of the operative intervention main stage (access to the kidney, dilatation of the nephrostomy channel, nephroureteroscopy, litholapaxy, nephrostomy drainage procedures) was $17.3 \pm 5.2$ minutes in average.

With calculi of the proximal part of ureter more than $0.8-1.0 \mathrm{~cm}$ and especially long standing (impacted), their movement into the renal cavity system was not always successful. In these cases, the retrograde ureteral catheter was placed distal to the calculus and the irrigation fluid, flowing through it, prevented calculus fragments distal migration when percutaneous antegrade ureterolithotripsy performing.

The mean time of percutaneous antegrade ureterolithotripsy (the main stage of the operation with the lithotripsy) was $58.5 \pm 15.4 \mathrm{~min}$, while the stone free rate was achieved in all $100 \%$ of patients. Such complications as bleeding were not noted, the mean level of hemoglobin drop was $15.5 \pm 5.4 \mathrm{GM} / \mathrm{DL}$. In the postoperative period there was a slight aggravation of pyelonephritis (subfebrility to 37.5 ) in $8(10.6 \%)$ patients, which was stopped by the antibacterial therapy intensification.

With long standing calculi in the ureter an internal ureteral $\mathrm{JJ}$ stent was placed by the antegrade method after the lithotripsy and litholapaxy. Thus, the nephrostomy drainage was placed in $24(32.0 \%)$ cases, nephrostomy drainage and internal ureteral $\mathrm{JJ}$ stent was placed in 33 $(44.0 \%)$, and the operation was ended with tubeless method and ureteral stent placement according to the Shpall method in $14(18.7 \%)$ cases. Nephrostomy drainage, as well as ureteral stants (with tubeless method), were removed in 1-2 days. The mean period of postoperative stay of patients in the hospital was $2.3 \pm 0.8$ days. The duration of the ureteral stent application was determined individually and it was $2.1 \pm 0.8$ weeks in average.

In the course of the work, we were faced with very important moments, both tactical and technical. Thus, access to the renal cavity system was performed as standard with the use of the mini-nephroscope tubes and we proceeded directly to contact lithotripsy of the calculus in the kidney or ureter after renal system examination. However, in cases where it was impossible to reach the calculus in the upper or middle third of the ureter by a nephroscope or as a result of calculus fragments distal migration along the ureter, the nephroscope was removed and a urethroscope (flexible or rigid) was entered through a tube to a point, where the calculus stands in the ureter, and the lithotripsy was performed there. The fragments were extracted with forceps 
or washed through the tube of the nephroscope (together with the ureteroscope) by intensive fluid flow through a pre-placed ureteral catheter.

Analyzing the procedure of percutaneous antegrade ureterolithotripsy performing and its results of treatment, it has been noted that the antegrade approach is a safe and effective option for ureteral calculi treatment in individual patients. And the use of the nephroscope tube allows for large fragments of calculi evacuation that significantly reduces the time of operation. These conclusions have been noted by previous researchers [7-10]. However, a number of authors believe that with large ureteral calculi the frequency of urethral injury and the percentage of ureteric stricture development in the antegrade approach are higher than in retrograde ureteroscopy $[9,10]$. To prevent these complications they recommend using a smaller caliber ureteroscope and avoiding the ureteral mucosal damage during lithotripsy, which is achieved using a flexible ureteroscope that usually has a smaller caliber than a rigid or semi-rigid ureteroscope, and using an ureteroscope with a casing can reduce friction between the mucosa ureter and ureteroscope. Also, the use of a laser lithotriptor avoids direct thermal damage and reduces the risk of mechanical mucosa damage by calculi fragments compared to other lithotripters.

However, in our opinion, the method of the anterograde flexible ureteroscopy has two peculiarities, on the one hand, it is of less traumatic treatment and allows the successful passage of "complex" ureteral areas, as well as a highly efficient for calculi lithotripsy, but on the other hand, it is extremely time-consuming and long-lasting at stages of lithotripsy and litholapaxy, especially with large calculi of the ureter (more than $1.0 \mathrm{~cm}$ ) and, importantly, cost demanding. Therefore, its use is necessary in complex cases of antegrade ureteroscopy.

\section{Conclusions}

Analysis of experience gained in urolithiasis with application of antegrade mini percutaneous ureterolithotripsy treatment indicates that this method is an attractive direction in the treatment of patients with large calculi of the proximal parts of ureter which are not suitable for retrograde ureteroscopy options, that allows achievement of the full state of stone free rate, reduction of not only the time of surgical treatment and the length of stay in the hospital, but also the number of repeated operations for residual calculi in patients with this pathology.

However, for this technique more active application more extensive and in-depth studies are needed.

\section{References}

[1] Türk, C., Petrík, A., Sarica, K., Seitz, C., Skolarikos, A., Straub, M., \& Knoll, T. (2016). EAU Guidelines on Interventional Treatment for Urolithiasis. European Urology, 69(3), 475-482. doi: 10.1016/j. eururo.2015.07.041.

[2] el-Nahas, A. R,. Eraky, I., el-Assmy, A. M., Shoma, A. M., el-Kenawy, M. R., Abdel-Latif, M., et al. (2006). Percutaneous treatment of large upper tract stones after urinary diversion. Urology, 68, 500-504. doi: 10.1016/j.urology.2006.03.065.

[3] Rhee, B. K., Bretan, P. N., \& Jr Stoller, M. L. (1999). Urolithiasis in renal and combined pancreas/renal transplant recipients. J. Urology, 161, 1458-1462. doi: 10.1016/S0022-5347(05)68926-4.

[4] Gupta, P. K. (2007) Is the holmium:YAG laser the best intracorporeal lithotripter for the ureter? A 3-year retrospective study. J. Endourol, 21, 305-309. doi: 10.1089/end.2006.0247.
[5] Wolf, J. S. (2007). Treatment selection and outcomes: ureteral calculi. Urol. Clin. North Am., 34, 421-430. doi: 10.1016/j.ucl.2007.04.010.

[6] Kumar, V., Ahlawat, R., Banjeree, G. K., Bhaduria, R. P., Elhence, A., \& Bhandari, M. (1996). Percutaneous ureterolitholapaxy: the best bet to clear large bulk impacted upper ureteral calculi. Arch. Esp Urol., 49, 86-91.

[7] Goel, R., Aron, M., Kesarwani, P. K., Dogra, P. N., Hemal, A. K., \& Gupta, N. P. (2005). Percutaneous antegrade removal of impacted upper-ureteral calculi: still the treatment of choice in developing countries. J. Endourol., 19, 54-57. doi: 10.1089/end.2005.19.54.

[8] Yuh-Shyan, Tsai, Yeong-Chin, Jou, Cheng-Huang, Shen, Chang-Te, Lin, Pi-Che, Chen, \& Ming-Chin, Cheng. (2015). Antegrade ureteroscopic assistance during percutaneous nephrolithotomy for complete renal staghorn stone: Technique and outcomes. Urological Science, 26 61-64. doi: https://doi.org/10.1016/j.urols.2014.09.002

[9] Winter, M., Lynch, C., Appu, S., \& Kourambas, J. (2011). Access sheath-aided percutaneous antegrade ureteroscopy; a novel approach to the ureter. BJU Int., 108(4), 620-622. doi: 10.1111/j.1464410X.2011.10538.x.

[10] Li, H., Na, W., Jiang, Y., Gu, X., Zhang, M., Huo, W., \& Kong, X. (2013) Percutaneous Nephro lithotomy Versus Ureteroscopic Lithotomy for Large (>15 mm) Impacted Upper Ureteral Stones in Different Locations: Is the Upper Border of the Fourth Lumbar Vertebra a Good Indication for Choice of Management Method? J. Endourology, 27(9), 1046-1050. doi: 10.1089/end.2012.0535.

\section{Information about authors:}

Sagalevich A. I., MD, PhD, DSc, Associate Professor, Department of Urology, National Medical Academy of Postgraduate Education named after P. L. Shupyk, Kyiv, Ukraine.

Vozianov A. S., MD, Assistant, Department of Urology, National

Medical Academy of Postgraduate Education named

after P. L. Shupyk, Kyiv, Ukraine.

Ozhohin V. V., MD, Postgraduate Student, Department of Urology,

National Medical Academy of Postgraduate Education named

after P. L. Shupyk, Kyiv, Ukraine.

Dzhuran B. V., MD, PhD, Associate Professor, Department

of Urology, National Medical Academy of Postgraduate Education named after P. L. Shupyk, Kyiv, Ukraine.

Kogut V. V., MD, PhD, Associate Professor, Department of Urology,

National Medical Academy of Postgraduate Education named after P. L. Shupyk, Kyiv, Ukraine.

Gaysenyuk F. Z., MD, PhD, DSc, Associate Professor, Department of Urology, National Medical Academy of Postgraduate Education named after P. L. Shupyk, Kyiv, Ukraine.

Sergiychuk R. V., MD, Postgraduate Student, Department of Urology, National Medical Academy of Postgraduate Education named after P. L. Shupyk, Kyiv, Ukraine.

\section{Відомості про авторів:}

Сагалевич А. І., А-р меА. наук, доцент каф. урології, Національна медична академія післядипломної освіти імені П. ^. Шупика, м. Київ, Україна.

Возіанов О. С., асистент каф. урології, Аоцент, Національна медична академія післядипломної освіти імені П. ^. Шупика, м. Київ, Україна.

Ожогін В. В., аспірант каф. урології, доцент, Національна медична академія післядипломної освіти імені П. ^. Шупика, м. Київ, Україна.

Ажуран Б. В., канд. меА. наук, доцент каф. урології, Національна медична академія післядипломної освіти імені П. ^. Шупика, м. Київ, Україна.

Когут В. В., канА. меА. наук, Аоцент каф. урології, Національна медична академія післяАипломної освіти імені П. ^. Шупика, м. Київ, Україна.

Гайсенюк Ф. З., А-р меА. наук, Аоцент каф. урології, Національна медична академія післядипломної освіти імені П. ^. Шупика, м. Київ, Україна.

Сергійчук Р. В., аспірант каф. урології, Аоцент, Національна медична академія післядип^омної освіти імені П. ^. Шупика, м. Київ, Україна.

\section{Сведения об авторах:}

Сагалевич А. И., А-р меА. наук, Аоцент каф. урологии, Национальная медицинская академия последипломного образования имени П. ^. Шупика, г. Киев, Украина. 
Возианов А. С., ассистент каф. урологии, Национальная меАицинская академия послеАипломного образования имени П. ^. Шупика, г. Киев, Украина.

Ожогин В. В., аспирант каф. урологии, Национальная меАицинская академия последипломного образования имени П. ^. Шупика, г. Киев, Украина.

Ажуран Б. В., канА. меА. наук, Аоцент каф. урологии,

Национальная медицинская академия последипломного образования имени П. ^. Шупика, г. Киев, Украина.

Когут В. В., канА. меА. наук, Аоцент каф. урологии,

Национальная меАицинская академия последипмомного образования имени П. ^. Шупика, г. Киев, Украина.

Гайсенюк Ф. 3., А-р меА. наук, Аоцент каф. урологии,

Национальная медицинская академия последипломного

образования имени П. ^. Шупика, г. Киев, Украина.

Сергийчук Р. В., аспирант каф. урологии, Национальная

медицинская академия последипломного образования имени

П. ^. Шупика, г. Киев, Украина.

Conflicts of Interest: authors have no conflict of interest to declare. Конфмікт інтересів: віАсутній.

Надійшла Ао редакції / Received: 14.08.2017

Після Аоопрацювання / Revised: 28.08.2017

Прийнято Ао Аруку / Accepted: 19.10.2017 